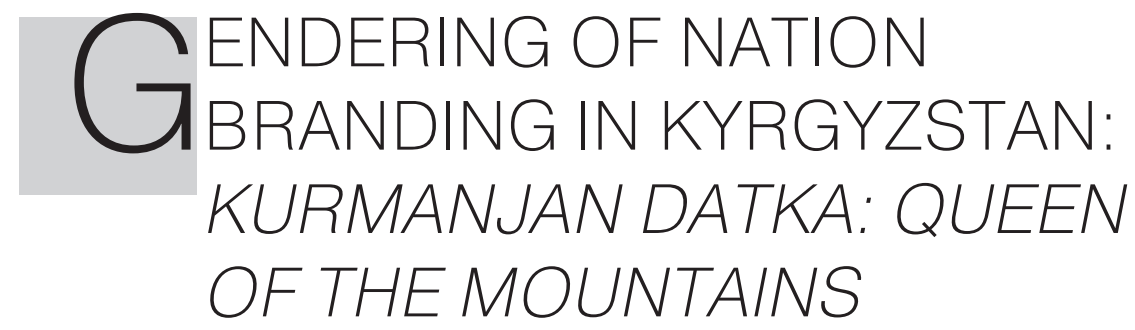

\title{
Snezhanna Atanova
}

Snezhanna Atanova, Institute of Oriental Studies, Russian Academy of Sciences. Address for correspondence: Institute of Oriental Studies RAS, ul. Rozhdestvenka, 12, Moscow, 107031, Russia. snej.atanova@gmail.com.

I would like to thank three anonymous reviewers for their careful reading of my manuscript and their many insightful comments and suggestions. I would also like to thank Marlene Laruelle and Christian Bleuer for their advice and help in improving the first draft of this article.

The article explores Kyrgyzstan's nation branding through the film Kurmanjan Datka: Queen of the Mountains (2014). While focusing on the nexus of gender and nation branding, I suggest that the cinematic narrative of the importance of women in national history has become an additional source for polishing the national image. To test this, I turn to the cinematographic plot and analyze the nation-branding activities, on the one hand, and the situation of women in independent Kyrgyzstan, on the other. First, the article explores how existing patriarchal tendencies limit aspirations of Kyrgyz authorities to project an image of Kyrgyzstan as democratic, modern, and progressive. This is especially evident when a film about a real-life woman hero that challenges the patriarchal attitudes becomes a tool of nation branding. Second, the article highlights that not only elites but also ordinary citizens can engage in nation-branding practices. The article is based on interviews with the film's producer and viewers, the heroine's descendants, feminist activists, experts on nation branding, and foreign tourists during fieldwork in Bishkek and Osh in Kyrgyzstan in 2017, 2018, and 2019, as well as on archival data and interviews with film's audiences in the United States.

Keywords: Nation Branding; Gender; Kyrgyzstan; Cinema; Central Asia

In 2017, during my first visit to Bishkek, I was walking in an oak park when I saw a monument to a woman in a majestic headdress. "Who is this?" I asked a friend. "Kurmanjan Datka, "tsaritsa of the Alai.'"

It was so amazing to hear about a heroine in the patriarchal realm of masculine heroes of Central Asia that I decided to learn as much as possible about her fate. This article is my dedication to the Kyrgyz woman datka. ${ }^{1}$

${ }^{1}$ Datka means "ruler" or "governor" in Kyrgyz. Tsaritsa is Russian for "tsarina." 
Since the collapse of the USSR, the post-Soviet countries have been strengthening their economic and political sovereignty while building their national image. Such an image, on condition that it should be distinct and positive, seems to be obligatory for every state entity that, by attempting to attract tourists, investors, international organizations, and so on, seeks to distinguish itself from other states on the world stage. Both the newer and longer-existing states cultivate their national images by using the practice of branding, a term borrowed from marketing and defined as the process by which companies mark their product offerings as distinct from those of the competition. The application of branding practices to nations is a relatively new concept, but it has become popular in recent years. As Keith Dinnie notes, "Nations are making increasingly conscious efforts to hone their country branding in recognition of the need to fulfill three major objectives: to attract tourists, to stimulate inward investment and to boost exports" (2007:17). In the era of international rivalry, nation branding can help increase international political influence, stimulate stronger international partnerships, and enhance nation building. Thus, oriented to external and internal audiences, nation branding transmits the image of a nation to domestic and international arenas.

Different approaches and tools can be employed in the task of nation branding. Among them, cinema holds a privileged position, as it makes accessible the image of a country to a large audience. Dedicated to the legendary figure, the 2014 film Kurmanjan Datka: Queen of the Mountains was created with financial help from Kyrgyz government. According to Jyldyz Djoldosheva, a Kyrgyz politician, founder of the Kurmanjan Datka Charitable Foundation, and the film's producer, the historical epic ${ }^{2}$ intended "to consolidate Kyrgyz people and to spread the word about a Kyrgyz woman hero to the world, to strengthen the Kyrgyz statehood, and to increase national consciousness" (interview with Djoldosheva, 2017). Thus, the film contributed to two processes: internal national consolidation and the branding of the nation through the creation of Kyrgyzstan's external image.

But how can a cinematographic story about a historical female figure contribute to national processes? Prominent scholars of nationalism, including Ernest Gellner, Antony Smith, Rogers Brubaker, and Michael Billig, highlighted the role of elites and intelligentsia in the conceptualization and dissemination of nationalist ideologies, but they omitted the biological, cultural, political, and symbolic role of women in the reproduction and formation of a nation (Yuval-Davis 1994). While the nature of women's citizenship is dual- "the state always includes women, at least to some extent, in the citizenry as a whole in its social, national, and legal policies, and, on the other hand, there is almost always a separate body of laws specifically addressed to women" - within the "imagined community" women became "symbols of the nation, its roots, its spirit, and its project" (Yuval-Davis 1994:91, 92). In this article exploring a narrative about a heroine and its significance for the nation branding of Kyrgyzstan, my theorizing proceeds from the constructivist approach to nationalism combined

2 I designate the film as a "historical epic" even though it presents an adapted version of historical events. 
with gender-based nuances of nationalist processes. When the state narratives interact with gender roles and norms, the latter are "negotiated, adapted, or contested by women themselves" (Cleuziou and Direnberger 2016:195). This point is discussed in scholarship on gender roles in the political and social landscape of modern Kyrgyzstan (Beyer and Kojobekova 2019; Ismailbekova 2014, 2015, 2016; Suyarkulova 2016), women and commemoration practices in Tajikistan (Roche 2012), gender politics in Soviet and post-Soviet Central Asia (Kandiyoti 1988, 2007), and women and religion in Uzbekistan (Fathi 2006).

This article is a contribution to the interdisciplinary research on gender and national processes in Central Asia, as it argues that the Kyrgyz government used a narrative about women's significance in national history for image-building purposes. The cinematographic story Kurmanjan Datka represents a source for both nation building and nation branding. The film was actively promoted to local and international audiences: it was released on Kyrgyz Republic's Independence Day in 2014, it was the first Kyrgyz movie shown in Hollywood, and it was nominated as Kyrgyzstan's entry for the best foreign language film Oscar award in the same year.

In what follows, I will not analyze the effectiveness of nation branding of Kyrgyzstan but will, rather, examine how the cinematic narrative devoted to a Kyrgyz national heroine fits in the country's nation branding and goes along with its nationbuilding projects. ${ }^{3}$ While drawing attention to the "feminine face" in nation branding, this study does not claim to cover in-depth such complex issues as gender, nation, and nation branding. Rather, it is an attempt to reflect on the relationship between gender and national image in one of the Central Asian countries, thus paving the way for further discussion of this topic in relation to other states in the region.

This article highlights the following findings. First, the cinematic work devoted to Kurmanjan Datka reflects various women's roles not just in Kyrgyzstan but in Central Asia more broadly: a daughter in a family where the father dreams of a son; a bride married against her will to an unloved man; a married woman subjected to male violence who did not bow her head and who had the courage to break patriarchal traditions; a faithful wife, a caring mother, and a guardian of the family hearth; a talented orator, a brave leader and warrior, an educated and intelligent ruler, protector of Kyrgyz tribes in the Alai Mountains. The cinematic story about events that happened a century ago develops in parallel with and in the context of gender problematics in modern Kyrgyzstan. Indeed, gender relations in a country with one of the worst scores on the Gender Inequality Index (United Nations Development Programme n.d.) are characterized by mutually opposite processes: on the one hand, a high level of violence against women and child marriages (UN Women n.d.) and, on the other, gender activism, among others feminist performances.

Second, this article highlights the significance of a female hero in the history of the Kyrgyz nation, as it demonstrates women's role in national processes in Kyrgyzstan. Therefore, the article attempts to show how a historical female figure is rele-

${ }^{3}$ Besides nation building, cinema can be employed in various activities related to a nation's image (see Isaacs 2015). 
vant to diversified national projects that target both local and international audiences and thereby to demonstrate how nation branding and nation building are intertwined in Kyrgyzstan. ${ }^{4}$

Third, this article discusses how the film conveys the state's discourse with its ethnocentric and nomadic vision of national identity. The nomadic ideas are reflected in the numerous initiatives aimed at the construction of a unique national image of Kyrgyzstan. The cinematographic narrative transmitted in Kurmanjan Datka forms an integral part of the Kyrgyzstan's nation-branding narrative. Since the 1990s, by taking various actions, the Kyrgyz state and non-state actors have been creating a metanarrative that emphasizes Kyrgyzstan's nomadic culture and targets international audience.

The article proceeds by exploring nation branding within a postmodern framework that considers a nation as invented and imagined through narrative, myths, and history. Therefore, both nation building and nation branding are imagined and constructed. The first "refers to a domestic process in which political elites (or state agents) attempt to overcome pre-existing cultural, ethnic, linguistic, or religious divisions in order to forge a national identity" (Hoefte and Veenendaal 2019:173), while the second is an externally oriented process to brand the nation in the most positive way.

\section{METHODOLOGY AND SOURCES}

This study consisted of several stages and stretched over several years. It draws primarily on the cinematic narrative of Kurmanjan Datka and a series of interviews conducted in 2017: first, with Joseph S. Nye, who coined the concept of "soft power," which is linked to nation branding (Nye 2004; see also Fan 2008), and also with two people who saw the film in Los Angeles. ${ }^{5}$ Both of them live in Los Angeles, and I met them through one of the participants of the UCLA Central Asia Workshop Annual Graduate Student Conference. Additionally, I conducted 14 interviews in Kyrgyzstan with several Kyrgyz officials, nation branding experts and practitioners, the producer of Kurmanjan Datka, with the descendants of the Kyrgyz heroine, foreign tourists in 0sh, and five ethnic Kyrgyz residents of Bishkek and Osh who had seen the film; all, with the exception of foreign visitors, had seen the film. ${ }^{6}$ The interviews in Kyrgyzstan were conducted in September 2017, June-July 2018, and August-September 2019. In 2020-2021, in search of additional information, I consulted archival documents from the State Archive of the Russian Federation (GARF). I also interviewed a film critic specializing in Kyrgyz films and Kyrgyz feminist activists via Facebook Messenger. Online media outlets, as well as information from international organizations and Kyrgyz government were used as a secondary-data source base.

${ }^{4}$ I do not argue that this phenomenon is of a permanent nature; however, national culture and history are tools often actively used to attract foreign visitors as well as to consolidate the unity of a country's citizens.

5 The interviews in Los Angeles were conducted in English.

${ }^{6}$ The interviews in Kyrgyzstan were conducted in Russian. 
This four-dimensional approach to data collection-cinematographic narrative, interviews, archival documents, and secondary sources - gives a solid foundation to answer the main questions of the study. I propose to consider this study as an invitation for future discussions about nationalism, nation branding, and gender in Central Asia.

\section{IDENTITY AND NATION BRANDING}

Imagining a national community is at the core of defining a nation. As Ernest Renan stated, "A nation is therefore a great solidarity, constituted by the feeling of the sacrifices we have made and those we are willing to make again" (1882:51). This idea was reformulated a century later by Benedict Anderson into the concept of "imagined community," which is "imagined because the members of even the smallest nation will never know most of their fellow-members, meet them, or even hear of them, yet in the minds of each lives the image of their communion" (2006:6).

Anderson's concept implies that the "national image" has at least two versions: the image existing among the members of one community about themselves and the image about the members of one community existing among the members of another community. I will not focus on either of these versions. Instead, I will explore what a national community wants to narrate to an external, international audience about themselves in order to create the image that it desires, as this selected narrative fulfills the objective of nation-branding activities. Nation-branding strategies have "domestic effects, because they can be employed by governments to enhance pride in the nation and thus promote social cohesion" (Kaneva 2012:3-22, quoted in Hoefte and Veenendaal 2019:174), particularly in a "nationalizing state" such as Kyrgyzstan, where the ruling elites promote the titular national group by means of language policy, symbols, and cultural reproduction. Together these elements compose part of the national-building narratives that target internal audiences and foster a common sense of belonging (Brubaker 2011). The same components seem to be used in nation-branding narratives that create a positive image of a titular nation (Jordan 2014:114) or of a national state (Marat 2009:1125).

As part of nation branding, a positive image, or "competitive identity" (Anholt 2007b), is promoted to the international and domestic public. "Competitive identity" seems to be associated with "national identity," as both highlight the exclusive nature of a nation compared to another. Distinguished by its exclusiveness, "national competitive identity" is constructed and promoted through six channels: brands, tourism, people, policy, investment, and culture (Anholt 2007b:26). It helps in attracting tourists, encouraging investors, adding value to exports, and so on. National competitive identity correlates with social identities of persons or states that, from a constructivist approach, are expected to stem from specific interests: "Identities are the basis of interests" (Wendt 1992:398). To explain, being an "athlete" suggests having interests in trainings and an active lifestyle, while an "academic" focuses on research, writing, and publication. Likewise, being a democratic state encourages support for demo- 
cratic values and politics. Alexander Wendt's theoretical approach implies that a state (as a person) projects whatever identity it pretends to be.

Wendt's conceptualization of the connection between identity and interests discovers the constructivist side of nation branding, and it goes along with Simon Anholt's (2007b) concept of a country's competitive identity, as well as with Peter van Ham's (2001) and Nadya Kaneva's views of branding as being a channel to project national sentiments "into an outward-oriented mode of collective identity" (2011:126). Furthermore, the concept of "soft power" is intertwined with nation branding, since the latter provides unlimited opportunities for achieving the desired results through attraction and persuasion rather that coercion (Nye 2004).

When I look closer at nation-branding policies and practices, I cannot but note that a country brings forward the most exclusive aspects of its identity. Being of cultural, political, or technological nature, these aspects may work well if they correspond to reality, like in the case of Japan that highlights its technological achievements (Anholt 2005:106-108) or France that emphasizes haute couture and grande cuisine. Or they may not, like in case of Russia, when doping scandals destroyed Russia's hopes for using athletic achievements in nation branding. This shows that a country is free to prioritize any aspects of its national identity that it considers the most exclusive, even those that are not backed by practical implementations. However, when a country promotes competitive aspects that are not backed by real achievements, this may have a negative effect and even harm the country's nation branding.

As Wally Olins (2002) argued, the idea of nation branding has always existed and history knows several examples of states that have restarted and created their national images anew every time their regime changed. Using the example of France, he demonstrated that the state had undergone numerous rebranding transformations, from Louis XIV to the Republic, from the Republic to the French Empire under Napoleon Bonaparte, and so on:

The France of the revolution was a completely different entity from the France of the Bourbons.... The tricolour replaced the fleur de lys, the Marseillaise became the new anthem, the traditional weights and measures were replaced by the metric system, a new calendar was introduced, God was replaced by the Supreme Being and the whole lot was exported through military triumphs all over Europe. In other words the entire French package was changed. You may not like the term, you may prefer to talk about a new or reinvented nation or state, but if revolutionary France was not a new brand I do not know what is. (0lins 2002:242)

Emerging from the ruins of the Soviet Union, the new states turned to branding practices in order to, among other things, get rid of the Soviet heritage in their images. Highlighting historical events, national heroes, and nomadic culture helped Kyrgyzstan to avoid associations with the Soviet legacy. At the same time, the newbrand image of the country was supposed to help compete with other countries in securing financial and political resources. 
Among the nations competing in the global arena, there are big countries whose national images are well known around the world and small countries whose national images are obscure for international audiences. Rich and big countries may have more financial and other resources, but even with limited resources small countries can benefit from nation branding. Anholt (2007a) points out that "a small, poor, remote or less-known country" can always find something special that would help distinguish it among large states. Together with improving their national image, both small and big nations can wield their "soft power", as Nye states (interview with Nye, 2017). There is a growing field of scholarship on how small, or "boutique," nations (Jansen 2008:133) undertake nation-branding activities and use their special features in order to create an attractive national image (Frasher et al. 2003; Jansen 2008; Olins 2002; Schultz and Hatch 1997). Research in this field shows that it is essential for a "boutique nation" to develop its own identity and thus find its niche in the world (Olins 2002; Schultz and Hatch 1997:338). To find its niche, a country can rely on existing cultural stereotypes, in other words, extract positive components from national stereotypes and "capitalize on them by targeting Western consumers who are searching for 'exoticism'" (Jansen 2008:133).

Cinema is one of the most powerful tools employed for expressing ideas about a nation (Hjort and MacKenzie 2000), a tool of which the Kyrgyz government took advantage. The film Kurmanjan Datka became a kind of national film that Kyrgyz authorities support in order to spread positive ideas about the nation and the country. The foundations of Kyrgyz cinematography were laid in the Soviet era. In the next section, I will consider the images of women that the cinematographic works of Soviet Kyrgyzstan offered.

\section{BACK TO SOVIET KIRGHIZIA}

In December 1937, Murat Salikhov, chairman of the Council of People's Commissars of the Kyrgyz Soviet Socialist Republic, sent Vyacheslav Molotov, chairman of the Council of People's Commissars of the Soviet Union, the following message:

As a result of the sabotage on the ideological front, which was carried out by the enemies of the people who are now discovered, the Kyrgyz SSR still does not have at its disposal to show on the republic's screens a single sound film in the Kyrgyz language, nor a film reflecting the life of the Kyrgyz people, their struggle for their liberation from the oppression of tsarism in the past and development during the years of Soviet power.

Meanwhile, there is a huge need to show the working masses of the Kyrgyz people all the achievements of the Soviet cinematography on screen and in their native language.

The Council of People's Commissars of the Kyrgyz SSR requests that you compel the relevant organizations producing films to translate (dub) our country's most popular films-Chapaev, We Are from Kronstadt, Maksim's Youth (2 parts), and Lenin in October-in the Kyrgyz language, as well as obligate these organizations to include production of one film from the heroic past of the Kyrgyz people 
(about the revolt of 1916) in the thematic plan of new films for 1938 and one film about the modern life. ${ }^{7}$

The request to translate the films from Russian into the language of the titular ethnic group of Soviet Kyrgyzstan demonstrates the privileging attitude towards the Kyrgyz language, which was a tool of cultural nationalism, while the selected films were used to legitimate the Soviet regime and ideology. Soviet officials emphasized cinema's role in propagating new ideas and values. As the first Soviet Minister of Education Anatolii Lunacharskii wrote (1924:11):

Cinema is a powerful tool. First of all, cinema disseminates scientific knowledge and ideas with the greatest visibility. Secondly ... cinema has all the features of art and, consequently, a great propaganda power that art has to offer.

It took 18 years, but the first Kyrgyz feature film was shot in 1955, and one year later the national film studio Kyrgyzfilm was founded (Oruzbaeva 1982:411). It is symbolic that the first Kyrgyz cinematic story was devoted to a heroine, Saltanat. Although the film was shot in Russian and by Russian film director Vasilii Pronin, all the roles were played by Kyrgyz actors. ${ }^{8}$ The film tells the story of a young woman, Saltanat, a zootechnician who, together with a young male scientist, Joomart, dreamed of modernizing agriculture in Soviet Kyrgyzstan. However, Saltanat's enthusiasm for her work and her companionship with Joomart provoked fierce jealousy of her husband, Aala. The film Saltanat promotes two ideological lines: the right of women to do the work they wish to do and on an equal footing with men, and the struggle of progress against retrogradism. It is interesting to note that several subsequent movies by Kyrgyzfilm were devoted to women: Moia oshibka (My mistake, 1957), Cholpon-utrenniaia zvezda (Cholpon is the morning star, 1959), Devushka Tian' Shania (The Tian Shan girl, 1959), and Toktogul (1960).

The first Kyrgyz films offered new gender representations and gender roles, and the women of Soviet Kyrgyzstan were shown as strong and striving for independence, as opposed to the dependent and oppressed women of prerevolutionary times. The films share a common storyline of the struggle between the oppressors-the patriarchal society with its representatives in the form of male antagonists - and the savior and liberator of women, the Soviet regime.

The release of the film Poklonis' ogniu (Bow to the fire, 1972) introduced the image of a heroine who is the master of her own destiny and is not looking for a man to protect her. The cinematic story depicts courageous revolutionary Urkuia Salieva, the

7 Salikhov's letter was referred for consideration to the Head Office of Cinematography, which informed that the request could be realized at the film studio Mosfilm and prescribed to the Committee on Arts of the Council of People's Commissars of the Kyrgyz Soviet Socialist Republic to find Kyrgyz language translators ("0 perevode zvukovykh kinofil'mov na kirgizskii iazyk i o vypuske kinofil'mov otrazhaiushchikh nuzhdy kirgizskogo naroda," GARF, f. P5456, op. 22, d. 4095).

8 According to Kyrgyz film critic Gulbara Tolomusheva, the first Kyrgyz movies were originally filmed in the Kyrgyz language, and then their scripts were translated into Russian at a film studio in Moscow (interview with Tolomusheva, 2021). 
chair of a collective farm and a member of the Central Executive Committee of the Kyrgyz Autonomous Republic, who fought for women's rights in the early 1930s and died at the hands of opponents of the Soviet power. Several years later, in 1978, a monument to the Fighters of the Revolution appeared on the central avenue of Frunze, the capital of Kyrgyzstan. On a pedestal made of granite stands a figure of a woman with a flag in her hand. The prototype of this woman was Urkuia Salieva (Limon.kg 2014). The monument to Kurmanjan Datka similarly stands in the center of the Kyrgyz capital (called Bishkek since 1991).

Despite similarities between the image of the revolutionary heroine from the movie Bow to the fire and Kurmanjan Datka, there are significant differences. First, Kurmanjan Datka is a story about a pre-Soviet heroine who, after the death of her husband, becomes not only the head of a large family but also the ruler of the Kyrgyz tribes of the Alai Mountains. Second, the film's dialogues present a symbolic image of the mother of all Kyrgyz (Aidarkanov 2019). Overall, the cinematic story about Kurmanjan Datka, created at the national film studio, symbolized both a new independent period in the history of Kyrgyz cinematography and the ability of state cinema to make professional movies, which has become another tool in the hands of the brand-new national state to realize national projects.

\section{GENDER AND NATION IN POST-SOVIET KYRGYZSTAN}

Before exploring the employment of cinema in national processes, it is necessary to observe the narratives on gender norms in the context of "nationalizing" policies in independent Kyrgyzstan. These policies not only include language and revised national histories designed to consolidate the hegemony of their respective titular nations but also target the family and gender relations (Kandiyoti 2007:610). De-Sovietization in all countries of the region has been marked by the return of "traditional" or patriarchal culture in form and in content.

The advancement of patriarchal values appears under the guise of seemingly innocent TV programs. For example, in February 2017 the state channel KTRK aired a reality show Kelin (Daughter-in-law) that highlighted participants' qualities of docility and good housekeeping (Im 2017). This TV show was criticized by Kyrgyz feminists and soon ended. ${ }^{9}$ In another example, in April 2021, Mother's Day was established as an annual holiday in the Kyrgyz Republic by a presidential decree, according to which "The tradition of respect and reverence of the mother, recognizing the importance of her role in bringing up children, strengthening the family, and contributing to the development of society, are deeply rooted in the people of Kyrgyzstan" (quoted in Ismailbekova 2016:268).

The TV show Kelin and Mother's Day give an insight into the attitudes about gender roles, signaling at the same time the abandoning of the Soviet-style women's emancipation and, therefore, the Soviet past and showing (neo)conservative tendencies in contemporary Kyrgyzstan. At the same time, attempts by the Kyrgyz parliament

9 A similar TV program also aired on Uzbek television (Kandiyoti 2007:612). 
to legalize polygamy (Ismailbekova 2016: 268), granting the official status of a cultural symbol of the Kyrgyz Republic to ak kalpak (Kyrgyz men's headwear made of felt), ak kalpak's inclusion on the Representative List of the Intangible Cultural Heritage of Humanity in 2019 (UNESCO Intangible Cultural Heritage n.d.a), and the celebration of Ak Kalpak Day (Abubakarova 2019) testify to the efforts to legitimize male privileges and attributes as part of the national culture. In the same vein, some segments of Kyrgyz society express positive reaction to ala-katchoo (bride kidnapping) (Iarmoshchuk, Zhetigenova, and Egemberdieva 2019). The custom that had been outlawed de jure since the Soviet period-and remains illegal under the 1994 Kyrgyz Criminal Code-has been traditionalized and continues to exist at the domestic level.

Speaking about the representation of gender roles in the public space, the political activism of mature women who are part of the Women's Units for Special Purposes $(O B O N)$ cannot be ignored. A group of protesting women calling themselves OBON first appeared during the 2005 Tulip Revolution, and since that time OBON's women have participated in political protests in Kyrgyzstan. The 2014 report of the independent organization Council of NGOs in Kyrgyzstan describes OBON as follows:

OBON is an established informal group, consisting mainly [of] women, purposefully formed and valid for the purposes of specific customers (government and other political structures, business, semi-criminal elements), regularly applying aggressive, violent, and illegal methods of work. OBON does not belong to true civil society groups, as it neither represents [its] own interests or the interests of vulnerable groups. (quoted in Beyer and Kojobekova 2019:336)

Most OBON women are socially and financially vulnerable, and their paid participation in protests does not reflect their "genuine political aspirations," but on the other hand their political activism allows them to achieve their economic needs or defend their citizenship rights, despite their actions being perceived as "shameful" within the existing patriarchal model (Beyer and Kojobekova 2019:341). Like mature women, male elders (aksakals) actively participate in the political life of the country, but their participation is perceived as traditional and is generally not condemned by society (Beyer and Kojobekova 2019). The opposite perceptions of essentially the same practice are an outcome of strict gender roles in a patriarchal context, where what is allowed for men is condemned for women.

"Nontraditional" OBON practices coexist with traditional roles as "keepers of the hearth and home" that Kyrgyz women use to gain access to power and status, both within and outside the family, and thus find "state legitimacy and greater opportunities for power and change in society" (Ismailbekova 2016:267). The legacy of "traditional patriarchy" is characteristic of the entire region of Central Asia, and women in Kyrgyzstan have to adapt to existed gender norms and apply the strategy of "patriarchal bargains" (Kandiyoti 1988). The latter allows women to gain their share of power and respect in Kyrgyz society. Of course, there are women in business, government, and parliament; however, their ratio is low: 17 percent in parliament during the 20162019 period, 28 percent in high-ranking business positions, and only 9 percent in government in 2020 (Kyrgyz Parliament 2016; Dzhamankulova 2020, 2021). 
Returning to the "patriarchal bargains," a relatively recent episode, which happened during the Feminnale "Kormilitsy. Economic Freedom. Women" that was held in Bishkek in December 2019, exhibited uyat (lit., "shame") practices under the guise of "traditional patriarchy." The Feminnale brought together feminist artists who called attention to women's labor and the associated workplace discrimination, harassment, and pay inequality. A "reverse stripping" performance by the Danish artist Julie Savery triggered a wave of resentment on the part of a right-wing nationalist group. ${ }^{10}$ As a result, Savery's performance together with several artworks was banned by a decree of the minister of culture, Azamat Zhamankulov. Antagonists of the exposition together with the minister himself "have appealed to the injured 'traditional' sensibilities of the common Kyrgyz people." The statement of the Artists' Union of Kyrgyzstan declared: "Despite the secular orientation of our state, we cannot ignore the feelings and mentality of the majority of Kyrgyz society, who maintain traditional values" (Suyarkulova 2020). Moreover, representatives of the right-wing nationalist groups threatened the organizers of this first feminist exhibition (interview with Kapalova, 2019; interviews with feminist activists, 2019, 2020). In this incident, repressive uyat practices are woven into the formulation of "traditional values." These practices condemn behavior and life choices and are a way to control women's bodies (Shelekpaev 2020). As in neighboring Kazakhstan, in Kyrgyzstan both men and women acted as authors of uyat repressions against artists demonstrating a naked female body, but as eyewitnesses testify, there were more men harshly condemning Feminnale and threatening its participants ${ }^{11}$ than women (interviews with feminist activists, 2019, 2020).

In the context of the above-mentioned gender policies and practices in Kyrgyzstan, how is the cinematographic story about Kurmanjan Datka used for national processes, and why can it be considered as an attempt at nation branding?

\section{LINKING CINEMA WITH NATION BRANDING}

When the Soviet Union collapsed, more than a dozen new states appeared on the world map. For most foreign audiences, every Central Asian republic was shrouded in mystery. It was particularly valuable at that time to construct and maintain a distinctive and positive national image. Different channels are employed to project a favorable image to the internal and external audiences. Among these channels, cinema-together with sporting mega-events like the Olympic Games or the FIFA World Cup, as well as the World Expos-is one of the most powerful forces to disseminate a country's image as widely as possible (Knott, Fyall, and Jones 2013; Magdalinski 2000). At the same time, there is only limited literature linking cinematic works with nation-branding activities. The cases from other countries provide analogies with Kyrgyzstan. Modest in size, New Zealand's cinema plays "an equally central role in the

10 Julie Savery initially appeared naked and then gradually put her clothes on. Her performance was designed to call public's attention to the stigmatization of sex workers.

11 These threats caused Mira Djangaracheva, director of the National Museum of Fine Arts in Bishkek, to resign. 
international dissemination of New Zealand brand," as does Spain's large film industry in the dissemination of the Spanish national image (Expósito 2011:143). Poland, whose film industry was shaped in the socialist Polish People's Republic and was used to promote Soviet ideas and values, made its first steps in combining nation branding with cinematography recently. Thus, while favoring historical events and authentic traditions, the Polish cinema seeks support from the countries considered as "the 'centers' of cinematography" (Hess and Najbor 2020:11). The case from Kyrgyzstan echoes the cases from New Zealand and Poland; therefore it serves as an additional example of the important role of cinematography in nation branding.

Nation branding is not owned by a country's government as it consists of all public discourses and messages (Expósito 2011:138), including cinematography. World powers have used cinema to propagate national image since the beginning of the twentieth century. American Hollywood and the Soviet film industry actively engaged in the representation of their countries on the big screen. From the musical comedies of Grigorii Aleksandrov to the historical dramas of Sergey Eisenstein, Soviet films were conceptualized to convey an ideological message in a popular and understandable form for various audiences. In other words, the historical storyline of Eisenstein's films had been used by Soviet officials to legitimize the current regime, to mold Soviet identity, and to project the image of the "country of Soviets" to external and internal audiences. Such films "provide a 'historical map' of the national past in order to bind the spectator more firmly to the present national identity" (Smith 2000:46-47). Kurmanjan Datka continues to some extent the traditions of the Soviet historical cinema, which pays attention to historical details, with their "atmosphere," period accessories, and so on.

Cinema certainly played a role in strengthening the Soviet power in all Soviet republics. Plans to translate film scripts about revolutionary heroes from Russian into Kyrgyz and to film the historical drama about the revolt of 1916 aimed to legitimize Soviet power and ideology among the Kyrgyz-speaking population. In other words, the main task of the "most important of the arts" (Lunacharskii 1965:41) was to "brand" the socialist revolution and the Soviets in the ethnic republics of the vast, multinational Soviet Union. In the era of the independent Kyrgyz state, its elites exploit cinema for similar purposes, except the Soviet supranational identity is replaced by Kyrgyz national identity. Therefore, the Soviet cinematic legacy may have been beneficial for film production in Kyrgyzstan, but was it?

\section{THE STORY OF KURMANJAN DATKA}

"Your daughter is worth ten sons. Our country will need her tomorrow." ${ }^{2}$ With these words begins the cinematic story of Kurmanjan Datka Mamatbaj Kyzy (1811-1907), the legendary ruler of the Kyrgyz Alai and Fergana from 1861 to 1901 . The film project was undertaken by Jyldyz Djoldosheva, who had been studying the life of Kurmanjan for several years. Djoldosheva learned about Kurmanjan Datka in the early 1980s:

12 Sadyk Sher-Niyaz, dir., Kurmanjan Datka: Queen of the Mountains, released in theaters August 22, 2014, video, 2:11:00, https://www.youtube.com/watch?v=I3H86R3zx3E. 
Once, I watched a documentary about Gustaf Mannerheim, an outstanding Finnish statesman. The broadcast featured historical photographs taken by him on the Alai during his expedition in 1906. There was the famous photograph of Kurmanjan. Since that time, I had a dream of telling [the story of] the great heroine of Kyrgyz people. (interview with Djoldosheva, 2017)

In the mid-1990s Djoldosheva set up the Kurmanjan Datka Charitable Foundation and began her research on the tsaritsa of the Alai, meeting with Kurmanjan's descendants and visiting the Uzbek National Archive in Tashkent to find rare documents on Kurmanjan's life. In the meantime, the charitable foundation completed several projects related to the Kyrgyz heroine: a monument in the center of Bishkek, two monographs, the ballet Kurmanjan Datka, and the documentary Queen of the Mountains (directed by Zamir Eraliev). Djoldosheva managed to convince the Kyrgyz authorities to allocate funds from the state budget for the historical epic about Kurmanjan Datka, and, with help from the national film studio Kyrgyzfilm, the shooting began in 2012, with the film set to be released in 2014 .

The historical events of the film go back to the nineteenth century. Not acquiescent to her forced marriage, young Kurmanjan escaped and married Alymbek Datka, a well-known political figure of the Kokand Khanate. The union between Kurmanjan and Alymbek was the first step in her lifelong quest to rule the Kyrgyz tribes of the Alai in this complex historical period. After her spouse died, Kurmanjan inherited his title datka and remained the sole ruler of the Alai region. In the second half of the nineteenth century when the Russian conquest spread the tsarist rule in Central Asia, Kurmanjan Datka announced the accession of the Alai Kyrgyz to Russia, thus saving it from bloodshed. In 1893 her youngest son Kamchibek was accused of murdering a customs officer and sentenced to execution. Datka could have called on the Kyrgyz tribes to revolt and freed her son, but it would have led to an armed clash and tragic consequences for the Alai Kyrgyz. Datka sacrificed her son's life for the Kyrgyz people.

The epic demonstrates and promotes three narratives: freedom of the spirit and wisdom of a Kyrgyz woman; national pride and the ability of Kyrgyz tribes to consolidate in times of crisis; and nomadic culture.

The main narrative focuses on the story of a woman who faced her own destiny. Having renounced an imposed marriage, Kurmanjan opposed patriarchal traditions, which was considered a disgrace by the conservative norms of her time. As a wise ruler and talented orator, she called for the unity of Kyrgyz tribes against the army of Kokand Khanate and she succeeded in doing so:

Kokand's army is powerful, and each life is precious. But aren't the freedom of our people and happiness of our children even more precious? You men may go. We women will stay. We swore not to let the enemy pass. Should the descendants of our great hero, Manas, simply run away?! It is better to die standing than to live on one's knees. Kyrgyz people have never died lying in their beds during war. What can be more honorable than to die for our Fatherland?... If we die, we'll die together. If we live, we will build our unified nation. 
As the battle scene shows, Kurmanjan was not afraid to fight the enemy. Datka was a strategist, and she acted in a decisive way in the circumstances that she faced. Therefore, she did not allow bloodshed when the Russian army entered the region, realizing the futility of resistance. Moreover, she was a mother who sacrificed her son for the greater good of the Kyrgyz people.

In all these contexts, Kurmanjan's character is manifested. Running away from her unloved fiancé, she opposed patriarchal traditions and committed a feminist act. Datka showed her strength when she gave patriotic speeches inspiring her compatriots to defend their native land.

One scene from the film is significant: Shabdan Dzhantaev in a letter to Kurmanjan Datka called her "the mother of the Alai people who has strived for the unification of all Kyrgyz people" and addressed her with the following words: "The time has come to unite the tribes living apart, no longer fighting amongst themselves." The words of the leader of the Northern Kyrgyz addressed to the ruler of the Southern Kyrgyz unequivocally called for the unification of the South and the North, and this call seems to be still relevant for today's Kyrgyzstan, where political elites of the South and the North are in constant confrontation. Political parallels shape the first argument about how Kurmanjan Datka fits into the nation building of independent Kyrgyzstan. The recognition of the Kyrgyz heroine and her celebration at the national level show that despite the domination of masculinity in the narratives of the nation (Nagel 1998), women sometimes fall into this chosen circle of national heroes.

Glorifying the role of Kurmanjan in Kyrgyz history, showing her leadership qualities and, one might say, feminist actions, the film demonstrates traditional gender realms of competence-the household and family (Beyer and Kojobekova 2019:2) and attitude towards women in the patriarchal Kyrgyz society. The plot of the film began with a scene where Kurmanjan's father asked a holy person for a blessing for the birth of a son; the next incident showed how a crowd of men intended to stone a young woman falsely accused of cheating on her husband; finally, Kurmanjan herself was subjected to aggression by her first husband's relative. Thus, the cinematic history of a woman in the end of the nineteenth century echoes the challenging gender mainstreaming in modern Kyrgyzstan, where feminist performances coexist with tragic cases of violence against women.

The multilayered cinematic narrative reflects both the building of the Kyrgyz nation and the role of women in this nation building. Multiple viewers who saw Kurmanjan Datka said that the film, devoted to a real Kyrgyz heroine, demonstrates that Kyrgyz women are strong and wise, and it shows the culture and traditions of the Kyrgyz people (interviews with viewers of the film, Kyrgyzstan, 2017, 2018).

Simultaneously, the story of the tsaritsa of the Alai fits easily into Kyrgyzstan's nation branding. Indeed, it provides various details of Kyrgyz life, bright traditional attire, felt carpets, demonstration of Kyrgyz customs, and delightful Kyrgyz landscapes: vast steppes, snow-capped mountains, pristine lakes, and verdant jailoo (pastures). The rich cultural and natural diversity of the country presented in the film does not only reflect the nomadic roots of Kyrgyzstan. The film looks like a cinematic version of the tourist website of the Kyrgyz Republic that invites potential tourists to 
visit the country where there is, according to the official slogan, "So much to discover!" (www.discoverkyrgyzstan.org). Together with the representation of the Kyrgyz heroine, these details provide the complex picture about the country that could be attractive for an international audience and be a source of pride for Kyrgyz citizens.

\section{NATION BRANDING WITHIN AND BEYOND KURMANJAN DATKA}

Official efforts on nation branding in Kyrgyzstan were initiated in 2007, when Prime Minister Almazbek Atambayev signed an order to form an expert working group for developing proposals for the creation of a national brand "Kyrgyzstan." However, practical measures to create an original, recognizable, and positive image of the republic began much earlier, soon after the country gained independence in 1991. Initiatives Manas-1000 and 0sh-3000 promoted the titular nation, along with historical personalities and myths. ${ }^{13}$ Projects such as "Kyrgyzstan is our common home" and "2200 years of Kyrgyz statehood" combined aspects of nation branding and nation building (Marat 2008). Thus, nation branding has been intertwined with nation building in Kyrgyzstan in several national projects of the republic since the 1990s.

In the meantime, a new approach to nation branding is emerging. It emphasizes the common nomadic heritage oriented towards, but not limited to, the neighboring countries: Kazakhstan, Turkmenistan, and Uzbekistan. Within this new approach, projects aimed at promoting national and even regional history and culture are emerging: the international folk crafts festivals Oimo and the World Nomad Games where all the countries of Central Asia participate, as well as adding sites spanning several countries of the region to the UNESCO lists of cultural heritage, ${ }_{1}^{14}$ and so forth. These initiatives indicate steps towards the promotion of tourism to the entire region of Central Asia, as well as the renewal of regional cooperation. ${ }^{15}$ It is during this period that the filming of Kurmanjan Datka began. Realized with substantial government support (budget of $\$ 1.5$ million), Kurmanjan Datka has become the highest-grossing Kyrgyz film to date. It is highly symbolic that the film was first released on August 31, 2014-Kyrgyzstan's Independence Day. The film's narrative emphasizes the significance of Kurmanjan Datka in the consolidation of Kyrgyz tribes in the Alai and Pamir Mountain regions, it suggests the consolidation of Kyrgyz people in their efforts to create a strong state, and it speaks to the "Kyrgyz nation" and in doing so contributes to the nation-building processes. According to Djoldosheva, about ten thousand extras participated in the large crowd scenes: "It was truly a national

${ }_{13}$ The projects were supported by the UN General Assembly's resolutions “Commemoration of the Millennium of the Kyrgyz National Epic, Manas" (1994) and "The 3000th anniversary of the city of Osh" (2000), as well as the proclamation by the United Nations of 2003 as the year of Kyrgyz statehood.

14 UNESCO World Heritage List and UNESCO List of Intangible Cultural Heritage.

15 The first regional meeting of the presidents of Central Asia took place in March 2018. Later that year, during its June plenary session, the UN General Assembly adopted a resolution on "Strengthening Regional and International Cooperation to Ensure Peace, Stability and Sustainable Development in the Central Asian Region." 
collaboration" (interview with Djoldosheva, 2017). These words indicate that the film had the support of the Kyrgyz population since its very inception.

Forgotten during the Soviet times, Kurmanjan Datka finally took her place among the most revered Kyrgyz personalities; the story of her life and struggle, once embodied on screen, became extremely popular in the country. This opinion is reflected the myriad of testimonies of Kyrgyz viewers (interviews with viewers of the film, Kyrgyzstan, 2017, 2018).

The film was actively promoted among the international public. It participated in several international film festivals like the Montreal World Film Festival (Kabarlar 2014), Fajr International Film Festival in Tehran (Radio Azattyk 2015), and others. Thus, Kurmanjan Datka has become part of a wider strategy of the Kyrgyz government to brand the independent Kyrgyz republic. It was also selected as the Kyrgyz entry for the Best Foreign Language Film at the 87th Academy Awards in 2014. The movie received personal support from Hollywood actor Sharon Stone, who considered the Kyrgyz epic as "a living, breathing brand for the nation to the outside world" (Canning 2014). Even though the film did not win the Academy Award, its red carpet premiere was held on November 4, 2014, at Hollywood's Egyptian Theatre. Then the film was screened at Laemmle Music Hall theater, attracting a multitude of viewers.

As one American viewer stated: "There were a lot of Kyrgyz guests among spectators on the day of movie screening. I could recognize them by felt hats. I was impressed by such collective support. That day I met Kyrgyz people, and I learned a bit about their culture and their country" (interviews with viewers of the film, USA, 2017). It is interesting that even those who did not participate in the screening of the film in person informed me about this event, particularly pointing out the felt hats-ak kalpaks - that Kyrgyz guests were wearing on that day (interviews with the UCLA conference participants, 2017). International spectators who watched the historical epic expressed interest in the film storyline about Kyrgyz female hero.

Kyrgyz film viewers perceive the cinematographic image of Kurmanjan Datka as conforming to "traditional" norms. Despite renouncing the imposed marriage, she acquired the high status of datka after the death of her husband Alymbek Datka; that is to say, the Kyrgyz heroine gained her status and power as a result of the traditions of patriarchalism. Furthermore, in the patriarchal context, when she sacrificed her own son for the homeland and for the lives of others, Kurmanjan Datka fulfilled her role as a woman and a mother (Cleuziou and Direnberger 2016). Among Western viewers the story about Kurmanjan Datka elicited a feminist interpretation as a tale of a woman who fights for her destiny and against patriarchal norms in Central Asia. They expressed interest in learning more about Kyrgyzstan.

The value of Kurmanjan Datka as a cinematic tool of nation branding is reflected and complemented by branding activities that emphasize Kyrgyz nomadic heritage, including the nominations related to nomadic culture to the UNESCO List of Intangible Cultural Heritage (UNESCO Intangible Cultural Heritage n.d.b). To highlight its nomadic heritage, Kyrgyzstan organized the World Nomad Games, an international 
sporting competition. ${ }^{16}$ According to an official Kyrgyz representative, "the core idea is not only to promote the country's image and create a competitive nation brand for the international public, but also to unite Kyrgyz citizens and get support from neighboring countries. On the other hand, the games boost the image of the whole Central Asian region in the world through sports, traditions, and handicrafts" (interview with Sultanov, 2017).

While reflecting the significance of the games for the nation building and nation branding of the country, these words confirm the commitment of the leadership to promote Kyrgyzstan as a country of the nomadic world and to rid itself of the Soviet legacy. Soviet anti-nomad policies practically destroyed nomadic societies in the entire region. In this context, an important point about gender roles in nomadic societies cannot be overlooked. Compared to sedentary societies where women were veiled and worked in the house, nomadic women enjoyed more freedom: they were unveiled, worked alongside the men, and were excellent riders. Accounts of the nineteenth-centurty European travelers descrbied the women nomads of Central Asia riding freely in the steppes and taking part in cultural and sporting events (Moser 1885; Vambery 1864). The World Nomad Games reflect the free spirit of the female nomad, and women actively participate in the competitions: in archery, in a traditional style of wrestling called Alysh (Moseman 2018), and so on. Altogether, the World Nomad Games, the cultural artifacts included on the UNESCO list of intangible heritage, the film Kurmanjan Datka, and other initiatives signal that the country's nation branding seeks to promote nomadic culture.

Despite the fact that all of the above initiatives are state led, nation branding is not owned by the country's government because "a brand is made up of all the public messages and discourses about the nation-many of which are of course in the hands of the State and its ideological apparatuses, but others come from private corporations, from individual citizens in their daily interactions" (Expósito 2011:138). Participation of citizens in nation branding is exemplified by a museum in the southern city of Osh devoted to the Kyrgyz heroine. The private museum, designated as the Alymbek Datka Museum and housed in a three-story yurt, was founded on the initiative of the descendants of Kurmanjan Datka and Alymbek Datka. It is located in the city center next to the National Historical and Archaeological Museum Complex and Sulaiman-Too Sacred Mountain, which is included in the UNESCO World Heritage List. During my several visits to 0 sh, I always saw foreign tourists in this yurt-museum. The museum has an extensive collection of household items from Kurmanjan Datka's home, as well as the pictures presenting the Kyrgyz heroine and her spouse Alymbek Datka. ${ }^{17}$ The museum visitors informed me that they are interested to learn about Kyrgyz culture: "We didn't know before about Kurmanjan Datka and Alymbek Datka, but now we do.... We are eager to discover more about Kyrgyzstan. The yurt-museum shows us the richness of nomadic culture, and it stimulates us to discover more" (interviews with foreign visitors, 2019). The statement speaks about the museum's role in promoting

16 The World Nomad Games were held on the shore of Lake Issyk-kul in 2014, 2016, and 2018.

${ }_{17}$ The historical value of the museum exhibits is complemented by explanatory information in English and Russian. 
Kyrgyz culture and shows how the tsaritsa of the Alai helps in the nation branding of Kyrgyzstan even beyond the narrative of the state-ordered cinema.

Osh residents characterize Kurmanjan Datka as "Kyrgyz national heroine," and some of them advised me to meet her descendants. During our conversation, Kurmanjan Datka's granddaughter and her namesake, Kurmanjan Abdykaparova, told me:

I am proud to bear the name of my grandmother. She is well known and respected all over the country. She did a lot for Kyrgyzstan and sacrificed her son for the homeland. Our family owns the museum and the café, where we are sitting now. The museum is devoted to both Kurmanjan Datka and her husband Alymbek Dat$\mathrm{ka}$, and we are glad to share the story of our family with foreign guests. (interview with Abdykaparova, 2017)

As Abdykaparova told me, the large family of Kurmanjan Datka's descendants included teachers, salesmen, small entrepreneurs, agricultural workers, and employees of the district administration. Each of them, as every resident of 0sh or every museum exhibit, disseminates images about the country, its culture and history. While doing so, while providing this information to foreign visitors, they contribute to nation branding.

The fact that the museum was founded by the descendants of the national heroine does not make it a unique case of nation branding led by private citizens, because each member of a national community personifies the whole country to a tourist, being a kind of an ambassador for their city or nation (Expósito 2011:139). However, the existence of the private museum devoted to Kurmanjan Datka continues and supplements the film about the heroine, because even those who have not seen the cinematic story after visiting the museum will be imbued with interest both in Kurmanjan herself and in Kyrgyzstan. The museum provides another facet of nation branding and nation building ${ }^{18}$ led by individual citizens. It allows individuals within and beyond Kyrgyzstan to interact with the narrative about Kurmanjan Datka and thereby to participate in national projects.

\section{CONCLUSION}

From a constructivist viewpoint nation branding can be seen as a continuation of processes of the emergence of nations and as the revitalization of national identity in the era of globalization. Nation-branding strategies are an area of responsibility and action of governments who undertake necessary steps to foster a country's favorable national image and promote a national competitive identity in the world. In doing so, authorities select what national narratives should project, as well as the sources and tools of nation branding.

In 2007 high-ranking Kyrgyz officials launched an initiative to create the country's brand. Since that time the nation-branding strategy with a strong focus on no-

18 The museum is a source of nation building, as its existence symbolizes the significance of Kurmandjan Datka for the Kyrgyz national community. 
madic culture has spread domestically and abroad. Accentuating the values of its nomadic culture has made the Kyrgyz Republic a benchmark of the whole region. As explained by a Kyrgyz expert on destination branding, "nomadism is the distinctive element of competitive identity of Kyrgyzstan. The country will continue promoting its nomadic culture to the entire world" (interview with Tchakiev, 2017).

Representatives of the different fields, including government, civic society, media, education, and others, favor nomadism as the key characteristic of the national image of Kyrgyzstan (interviews with Tchakiev, 2017; Sultanov, 2017; Djoldosheva, 2017; Khasanov and Golovash 2017). Emphasizing traditional culture and natural landscapes, the cinematographic narrative of Kurmanjan Datka, together with the cultural practices and artifacts put on the UNESCO heritage lists and the World Nomad Games, offers its version of national image for export.

Against the backdrop of picturesque landscapes in the atmosphere of the Kyrgyz nomad camps, the story devoted to a female hero develops. The film promotes a gender-oriented narrative, prompting reflection on women's role in the national processes. Various feminine hypostases presented in the film-a bride dependent on the will of the fiancé or father, a faithful spouse, a caring mother, and a wise woman leader-reflect a complex gender agenda in the modern Kyrgyzstan, where "traditionalized" violation of women coexist with feminist manifestations. The contested nature of women's roles in the Kyrgyz nationhood is reflected in violence against women, bride-kidnapping and the women of OBON, the TV show Kelin and Mother's Day, the first Feminnale of Contemporary Art and extremely negative state-led reaction against it, the official celebration of the International Women's Day and the march of Kyrgyz feminists on the same day.

The purpose of this article was to rethink the women's involvement in nation building and nation branding, and even though the data on which this article relies is limited, it builds a strong foundation for a discussion about women's role in national processes in Central Asia. Additionally, I suggest that despite the presumption about monopoly of the ruling elites on nation branding in Central Asia, nonofficial actors could be equally engaged in branding practices. The museum devoted to the national heroine Kurmanjan Datka in 0sh is an example of such engagement. It would be useful to explore in more detail how nonofficial actors participate in nation branding in Kyrgyzstan and other countries of the region.

\section{REFERENCES}

Abubakarova, Tamara. 2019. “Deputaty Zhogorku Kenesha odobrili prisvoenie ak-kalpaku statusa kul'turnogo simvola Kyrgyzstana." Informburo, February 27. https://informburo.kz/novosti /deputaty-zhogorku-kenesha-odobrili-prisvoenie-ak-kalpaku-statusa-kulturnogo-simvola -kyrgyzstana-.html.

Aidarkanov, Islam. 2019. "Svobodnaia ili nesvobodnaia zhenshchina Vostoka? Obraz 'zhenshchiny' v kyrgyzskom kinematografe." Central Asian Analytical Network, December 4. https://www .caa-network.org/archives/18706.

Anderson, Benedict. 2006. Imagined Communities: Reflections on the Origin and Spread of Nationalism. London: Verso.

Anholt, Simon. 2005. Brand New Justice: The Upside of Global Branding. 0xford: Butterworth-Heinemann. 
Anholt, Simon. 2007a. "Anholt: Countries Must Earn Better Images through Smart Policy." Interview by Lee Hudson Teslik. Council of Foreign Relations, November 6. https://www.cfr.org /interview/anholt-countries-must-earn-better-images-through-smart-policy.

Anholt, Simon. 2007b. Competitive Identity: The New Brand Management for Nations, Cities and Regions. London: Palgrave Macmillan.

Beyer, Judith, and Aijarkyn Kojobekova. 2019. “Women of Protest, Men of Applause: Political Activism, Gender and Tradition in Kyrgyzstan." Central Asian Survey 38(3):329-345. https://doi.org /10.1080/02634937.2019.1631258.

Brubaker, Rogers. 2011. “Nationalizing States Revisited: Projects and Processes of Nationalization in Post-Soviet States." Ethnic and Racial Studies 34(11):1785-1814. https://doi.org/10.1080 /01419870.2011.579137.

Canning, Emily. 2014. “The Two Films inside Kyrgyzstan's 'Kurmanjan Datka."” Radio Free Europe/ Radio Liberty, December 30. http://www.rferl.org/a/kurmanjan-datka-queen-of-the -mountains-kyrgyzstan-film/26769501.html.

Cleuziou, Juliette, and Lucia Direnberger. 2016. “Gender and Nation in Post-Soviet Central Asia: From National Narratives to Women's Practices." Nationalities Papers 44(2):195-206. https:// doi.org/10.1080/00905992.2015.1082997.

Dinnie, Keith. 2007. Nation Branding: Concepts, Issues, Practice. London: Butterworth-Heinemann.

Dzhamankulova, Aizhamal. 2020. "Zhenshchiny u rulia gosorganov KR—skol'ko ikh? 0 sootnoshenii polov vo vlasti." Sputnik, January 27. https://ru.sputnik.kg/infographics /20200127/1046885559/kyrgyzstan-pravitelstvo-vlast-gosorgan-zhenshchiny-muzhchiny .html.

Dzhamankulova, Aizhamal. 2021. “Odnim postom: 8 faktov o gendernom neravenstve v Kyrgyzstane." Kloop, January 8. https://kloop.kg/blog/2021/01/08/odnim-postom-8-faktov-0 -gendernom-neravenstve-v-kyrgyzstane/?fbclid=IwAR1bCFW6gpwb-285yg_Xaa07rOPzyZjp -Ne9i7URXgJrYTW2MFqVlV63Xv-M.

Expósito, Alfredo Martínez. 2011. "Screening Nation Brands: New Zealand and Spanish Perspectives on Film and Country Image." Journal of New Zealand Studies 11:135-149. https://doi .org/10.26686/jnzs.v0i11.506.

Fan, Ying. 2008. "Soft Power: Power of Attraction or Confusion?" Place Branding and Public Diplomacy 4(2):147-158. https:/doi.org/10.1057/pb.2008.4.

Fathi, Habiba. 2006. "Gender, Islam, and Social Change in Uzbekistan." Central Asian Survey 25(3):303-317. https://doi.org/10.1080/02634930601022575.

Frasher, Spencer, Michael Hall, Jeremy Hildreth, and Mia Sorgi. 2003. A Brand for the Nation of Latvia. Oxford: Oxford Said Business School.

Hess, Agnieszka, and Joanna Najbor. 2020. "Promotion of Polish Cinema Abroad as an Element of Nation Branding: Case Study of 'Cold War' (2018) by Pawel Pawlikowski." Sustainability 12(14):5621. https://doi.org/10.3390/su12145621.

Hjort, Mette, and Scott MacKenzie, eds. 2000. Cinema and Nation. London: Routledge.

Hoefte, Rosemarijn, and Wouter Veenendaal. 2019. "The Challenges of Nation-Building and Nation Branding in Multi-Ethnic Suriname." Nationalism and Ethnic Politics 25(2):173-190. https:// doi.org/10.1080/13537113.2019.1602371.

Iarmoshchuk, Tat'iana, Alina Zhetigenova, and Zhazgul' Egemberdieva. 2019. "God bez Burulai: Potchemu v Kyrgyzstane zagovorili o traditsii pokhishcheniia nevest posle ubiistva devushki." Currenttime.tv, May 27. https://www.currenttime.tv/a/ala-kachu-kyrgyzstan-burulai /29965339.html.

Im, Regina. 2017. “Realiti-shou 'Kelin': Chto govoriat za i protiv teleproekta?" Kloop, February 8. https://kloop.kg/blog/2017/02/08/realiti-shou-kelin-chto-govoryat-za-i-protiv -teleproekta/.

Isaacs, Rico. 2015. "Nomads, Warriors and Bureaucrats: Nation-Building and Film in Post-Soviet Kazakhstan." Nationalities Papers 43(3):399-416. https://doi.org/10.1080/00905992.2013 .870986 . 
Ismailbekova, Aksana. 2014. "Migration and Patrilineal Descent: The Role of Women in Kyrgyzstan." Central Asian Survey 33(3):375-389. https://doi.org/10.1080/02634937.2014.961305.

Ismailbekova, Aksana. 2015. "Single Mothers in Osh: Well-Being and Coping Strategies of Women in the Aftermath of the 2010 Conflict in Kyrgyzstan." Focaal: Journal of Global and Historical Anthropology 71:114-127. http://dx.doi.org/10.3167/fcl.2015.710110.

Ismailbekova, Aksana. 2016. "Constructing the Authority of Women through Custom: Bulak Village, Kyrgyzstan." Nationalities Papers 44(2):266-280. https://doi.org/10.1080/00905992.2015 .1081381.

Jansen, Sue Curry. 2008. “Designer Nations: Neo-Liberal Nation Branding—Brand Estonia." Social Identity 14(1):121-142. https://doi.org/10.1080/13504630701848721.

Jordan, Paul. 2014. The Modern Fairy Tale: Nation Branding, National Identity and the Eurovision Song Contest in Estonia. Tartu, Estonia: University of Tartu Press.

Kabarlar. 2014. “Sozdateli fil'ma 'Kurmanzhan Datka' pribyli v Monreal' (Kanada) dlia podgotovki k uchastiiu v kinofestivale." August 18. https://kabarlar.org/news/28801-sozdateli-filma -kurmanzhan-datka-pribyli-v-monreal-dlya-podgotovki-k-uchastiyu-v-kinofestivale.html.

Kandiyoti, Deniz. 1988. "Bargaining with Patriarchy." Gender and Society 2(3):274-290. https:// doi.org/10.1177/089124388002003004.

Kandiyoti, Deniz. 2007. "The Politics of Gender and the Soviet Paradox: Neither Colonized, Nor Modern?"Central Asian Survey 26(4):601-623. https://doi.org/10.1080/02634930802018521.

Kaneva, Nadya. 2011. "Nation Branding: Toward an Agenda for Critical Research." International Journal of Communication 5:117-141.

Knott, Brendon, Alan Fyall, and Ian Jones. 2013. "The Nation-Branding Legacy of the 2010 FIFA World Cup for South Africa." Journal of Hospitality Marketing \& Management 22(6):569-595. https://doi.org/10.1080/19368623.2012.663155.

Kyrgyz Parliament. 2016. "Zhenshchiny deputaty VI sozyva Zhogorku Kenesha Kyrgyzskoi Respubliki." October 12. http://kenesh.kg/.

Limon.kg. 2014. "Lichnost' Kyrgyzstana: Borets za svobodu Urkuia Salieva." October 15. https:// limon.kg/news:63802.

Lunacharskii, Anatolii. 1924. "Revoliutsionnaia ideologiia i kino." Kino-Nedelia, no. 46, 11.

Lunacharskii, Anatolii. 1965. 0 kino: Stat'i, vyskazyvaniia, stsenarii, dokumenty. Moscow: Iskusstvo.

Magdalinski, Tara. 2000. "The Reinvention of Australia for the Sydney 2000 Olympic Games." International Journal of the History of Sport 17(2-3):305-322. https://doi.org/10.1080 /09523360008714138.

Marat, Erica. 2008. "National Ideology and State-Building in Kyrgyzstan and Tajikistan." Silk Road Paper, Central Asia-Caucasus Institute \& Silk Road Studies Program, January.

Marat, Erica. 2009. "Nation Branding in Central Asia: A New Campaign to Present Ideas about the State and the Nations." Europe-Asia Studies 61(7):1123-1136. https://doi.org/10.1080 /09668130903068657.

Moseman, Eleanor. 2018. "Women of the World Nomad Games-In Pictures." Guardian, September 18. https://www.theguardian.com/world/gallery/2018/sep/18/women-of-the-world-nomad -games-in-pictures.

Moser, Henri. 1885. À travers l'Asie Centrale: La steppe kirghize, le Turkestan russe, Boukhara, Khiva, le pays des Turcomans et la Perse, impressions de voyage. Paris: Plon.

Nagel, Joanne. 1998. "Masculinity and Nationalism: Gender and Sexuality in the Making of Nations." Ethnic and Racial Studies 21(2):242-269. https://doi.org/10.1080/014198798330007.

Nye, Joseph. 2004. Soft Power: The Means to Success in World Politics. New York: Public Affairs.

Olins, Wally. 2002. "Branding the Nation: The Historical Context." Journal of Brand Management 9(4):241-248. https://doi.org/10.1057/palgrave.bm.2540075.

Oruzbaeva, Biubiina, ed. 1982. Kirgizskaia Sovetskaia Sozialisticheskaia Respublika. Frunze: Glavnaia redaktsiia Kirgizskoi sovetskoi entsiklopedii.

Radio Azattyk. 2015. “Kinokartina 'Kurmanzhan Datka' udostoena spezial'nogo priza zhuri na kinofestivale v Tegerane." May 4. https://rus.azattyk.org/a/26992224.html. 
Renan, Ernest. 1882. Qu'est-ce qu'une nation? Paris: Sorbonne.

Roche, Sophie. 2012. "Gender in Narrative Memory: The Example of Civil War Narratives in Tajikistan." Ab Imperio 3:279-307. https://doi.org/10.1353/imp.2012.0089.

Schultz, Majken, and Mary Jo Hatch. 1997. "A European View on Corporate Identity: An Interview with Wally Olins." Journal of Management Inquiry 6(4):330-339. https://doi.org /10.1177/105649269764009.

Shelekpayev, Nari. 2020. “Govorit' so stisnutymi zubami: Styd, vlast' i zhenskoye telo v sovremennom Kazakhstane." Novoe literaturnoe obozrenie 161(1):157-174. https://www.nlobooks.ru /magazines/novoe_literaturnoe_obozrenie/161_nlo_1_2020/article/21977/?fbclid=IwAR0J QiSRw80FZdsI6nkL7Vdov0yua83AdgdCSidQIXMLloA8mF_J9tCd1Yg.

Smith, Antony. 2000. "Images of the Nation: Cinema, Art and National Identity." Pp. 41-53 in Cinema and Nation, ed. by Mette Hjort and Scott MacKenzie. London: Routledge.

Suyarkulova, Mohira. 2016. "Fashioning the Nation: Gender and Politics of Dress in Contemporary Kyrgyzstan." Nationalities Papers 44(2):247-265. https://doi.org/10.1080/00905992.2016 .1145200 .

Suyarkulova, Mohira. 2020. “Fateful Feminnale: An Insider's View of a 'Controversial' Feminist Art Exhibition in Kyrgyzstan." OpenDemocracy, January 9. https://www.opendemocracy.net/en /odr/fateful-feminnale-an-insiders-view-of-a-controversial-feminist-art-exhibition-in -kyrgyzstan/.

UNESCO Intangible Cultural Heritage. N.d.a. “Ak-kalpak Craftsmanship, Traditional Knowledge and Skills in Making and Wearing Kyrgyz Men's Headwear." https://ich.unesco.org/en/RL/ak-kalpak-craftsmanship-traditional-knowledge-and-skills-in-making-and-wearing-kyrgyz-mensheadwear-01496.

UNESCO Intangible Cultural Heritage. N.d.b. “Browse the Lists of Intangible Cultural Heritage and the Register of Good Safeguarding Practices." https://ich.unesco.org/en/lists?text=\&countr $y[]=00116 \&$ multinational=3\&display1=inscriptionID\#tabs.

United Nations Development Programme. N.d. "Human Development Reports." Table 5: Gender Inequality Index. http://hdr.undp.org/en/composite/GII.

UN Women. N.d. "Global Database on Violence against Women, Kyrgyzstan." https://evaw-globaldatabase.unwomen.org/en/countries/asia/kyrgyzstan?formofviolence=fac5fe48636e4d388 2bbd2ebbf29bd60\#1.

Vambery, Armin. 1864. Travels in Central Asia: Being the Account of a Journey from Teheran across the Turkoman Desert on the Eastern Shore of the Caspian to Khiva, Bokhara, and Samarkand. London: John Murray.

Van Ham, Peter. 2001. “The Rise of the Brand State: The Postmodern Politics of Image and Reputation." Foreign Affairs 80(5):2-6.

Wendt, Alexander. 1992. "Anarchy Is What States Make of It: The Social Construction of Power Politics." International Organization 46(2):391-425.

Yuval-Davis, Nira. 1994. "Les femmes et le nationalisme." Trans. Nancy Bolain. "Les femmes et la construction européenne," special issue, Les Cahiers du GRIF 48:89-96.

\section{LIST OF INTERVIEWS}

Aziz Khasanov and Stepan Golovash, creators of promotional videos of Kyrgyzstan, interviewed in September 2017.

Altyn Kapalova, curator of the first Feminnale in Bishkek, interviewed in December 2019.

Feminist activists from Bishkek, interviewed in December 2019 and September 2020.

Foreign visitors to the private museum of Kurmanjan Datka and Alymbek Datka in 0sh, interviewed in July 2019.

Gulbara Tolomusheva, Kyrgyz film critic, interviewed in March 2021.

Jyldyz Djoldosheva, producer of Kurmanjan Datka: Queen of the Mountains, interviewed in September 2017. 
Kurmanjan Abdykaparova, granddaughter of Kurmanjan Datka, interviewed in September 2017.

Maksat Tchakiev, expert on nation/destination branding of Kyrgyzstan, interviewed in September 2017.

Joseph S. Nye Jr., Professor Emeritus, Harvard University, interviewed in February 2017.

Participants at the UCLA conference, interviewed in Los Angeles in April 2017.

Talant Sultanov, advisor to the prime minister of Kyrgyzstan, interviewed in February 2017.

Six viewers of the film Kurmanjan Datka: Queen of the Mountains, interviewed in Bishkek and Osh in

September 2017 and July 2018.

Two viewers of the film Kurmanjan Datka: Queen of the Mountains, interviewed in Los Angeles in

April 2017.

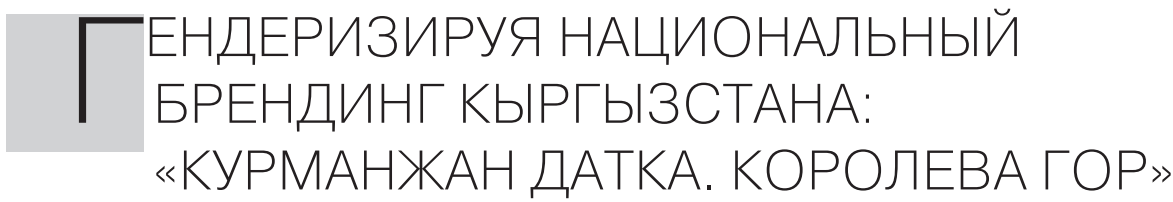

\section{Снежанна Атанова}

Снежанна Атанова, Центр изучения Центральной Азии, Кавказа и УралоПоволжья, Институт востоковедения РАН. Адрес для переписки: Институт востоковедения РАН, ул. Рождественка, 12, Москва, 107031, Россия. snej.atanova@gmail.com.

Статья исследует национальный брендинг Кыргызстана, опираясь в качестве примера на фильм «Курманжан Датка. Королева гор» (2014). Связывая гендер и национальный брендинг, автор предполагает, что кинематографическое повествование о важности женщин в национальной истории стало дополнительным источником для улучшения образа страны. Для проверки этого предположения автор обращается к сюжету кинофильма и анализирует национальный брендинг страны, с одной стороны, и положение женщин в независимом Кыргызстане - с другой. Статья исследует, как существующие патриархальные нормы ограничивают стремления кыргызских властей к продвижению образа Кыргызстана как демократического, прогрессивного и современного государства. Последнее особенно заметно в случае, когда инструментом национального брендинга становится фильм о реальной женщине-героине, оспаривающий патриархальные тенденции. Также автор обращает внимание на то, что в практиках национального брендинга могут участвовать не только элиты, но и простые граждане. Статья основана на интервью с продюсером и зрителями фильма, с потомками кыргызской героини, с феминистскими активистками, представителями кыргызских властей, экспертами и иностранными туристами, собранных во время полевых исследований в Бишкеке и Оше, в Кыргызстане, в 2017, 2018 и 2019 годах, а также на архивных материалах и интервью со зрителями фильма, проведенных в Соединенных Штатах.

Ключевые слова: национальный брендинг; гендер; Кыргызстан; кино; Центральная Азия 